\title{
SPATIAL AND TEMPORAL VARIATIONS IN SEISMICITY IN THE IMPERIAL VALLEY (1902-1984)
}

\author{
By Diane I. Doser and Hiroo Kanamori
}

\begin{abstract}
Earthquakes with $M_{L} \geqq 4.5$ that occurred between 1932 and 1973 in the Imperial Valley region and their related foreshocks and aftershocks are relocated using station delays derived from calibration events that were well recorded at regional distances between 1979 and 1981 . The relocated seismicity shows that there was an increase in seismicity in regions northeast of the Imperial fault 5 to 6 yr prior to the $1940\left(M_{s}=7.1\right)$ Imperial Valley earthquake. A study of intensity reports for felt earthquakes prior to 1932 also suggests an increase in seismicity in regions surrounding the Imperial fault as early as 1917. Isoseismal patterns, description of the mainshock sequence, and patterns of seismicity before and after the 1915 Imperial Valley earthquakes suggest that the earthquakes occurred off the Imperial fault. In this case, seismicity between 1906 and 1940 would nearly encircle the portion of the Imperial fault that ruptured during 1940. In both the 1940 and 1979 Imperial Valley earthquake sequences, aftershocks of $M_{L} \geqq 4.5$ occurred only for 2 months following the mainshock. The aftershock sequences were followed by periods of quiescence lasting up to $10 \mathrm{yr}$ in the region within $30 \mathrm{~km}$ of the mainshock. This is in contrast to $M_{L}>\mathbf{6 . 0}$ earthquakes occurring near the edges of the Imperial Valley that had aftershocks of $M_{L} \geqq 4.5$ occurring for up to $4 \mathrm{yr}$ after the mainshock. These differences may be related to the high heat flow within the Imperial Valley.
\end{abstract}

\section{INTRODUCTION}

Earthquakes in the Imperial Valley, one of the most seismically active regions of southern California, are characterized by swarm sequences along the Brawley Seismic Zone (Johnson, 1979) and adjacent regions (Figure 1), and occasional $M_{L}$ $\geqq 5.0$ mainshocks with accompanying aftershocks. Studies of seismicity patterns over the last 50 to $75 \mathrm{yr}$ in the Imperial Valley may reveal changes in seismicity that have preceded these swarm or mainshock sequences, and will serve to increase our knowledge of regional earthquake cycles and the interaction between fault systems in the region.

We have attempted to relocate all $M_{L} \geqq 4.5$ earthquakes occurring in the region between 1932 and 1973 to study spatial and temporal changes in seismicity. (Prior to 1932, phase information was not routinely recorded at Caltech. Since April of 1973, a dense seismic network has been operating in the Imperial Valley, enabling precise locations of $M_{L} \geqq 2.5$ earthquakes with epicenter errors of less than $\pm 2 \mathrm{~km}$.) Aftershocks, defined as earthquakes occurring within $30 \mathrm{~km}$ and 2 months of a $M_{L}$ $\geqq 4.5$ earthquake, and foreshocks, defined as earthquakes occurring within 2 days and $30 \mathrm{~km}$ of a $M_{L} \geqq 4.5$ event, were also relocated.

Several previous studies (Ulrich, 1941; Wood, 1941; Johnson, 1979; Johnson and Hill, 1982) have discussed pre-1973 seismicity in the Imperial Valley, but none have attempted to relocate earthquakes listed in the Caltech catalog or compared the catalog locations to felt reports. Important spatial variations in seismicity could be missed by the exclusive study of catalog locations, since many pre-1973 earthquakes were located on the basis of felt reports and aftershocks were often given the same locations as the mainshock. It is also difficult to estimate the location errors associated with catalog epicenters because many were located using graphical 
techniques coupled with felt reports. The earthquakes we have relocated and carefully sorted for quality thus provide better detail of spatial variations in seismicity and, perhaps more importantly, estimates of location error.

Felt earthquakes with Modified Mercalli intensities greater than V occurring between the settlement of the region in 1902 (Cory, 1913) and 1932 were crudely located using intensity reports. Isoseismals for these felt earthquakes were also compared with isoseismals for instrumentally located events. The pre-1932 locations and the instrumental relocations were then combined to examine spatial patterns in seismicity and moment release through time for six subregions of the Imperial Valley.

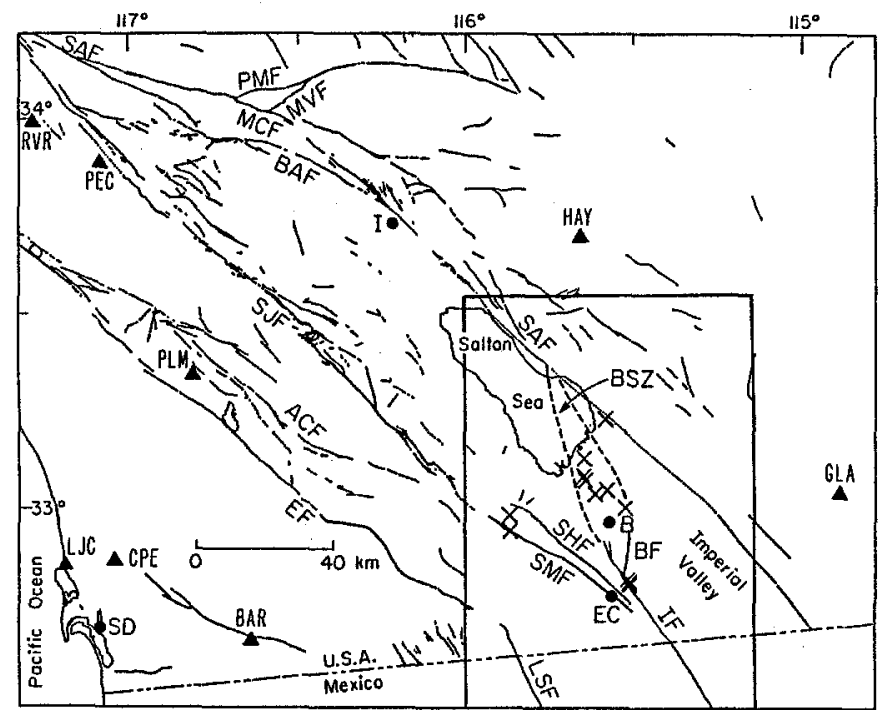

FIG. 1. Map of southwestern California showing major fault systems. Stations used in relocations are denoted by triangles and are listed in Table 2 . Cities are denoted by dots. SD, San Diego; EC, El Centro; B, Brawley; I, Indio. Faults are abbreviated in this and following figures as: SJF, San Jacinto fault; ACF, Agua Caliente fault; EF, Elsinore fault; SHF, Superstition Hills fault; SMF, Superstition Mountain fault; LSF, Laguna Salada fault; IF, Imperial fault; BF, Brawley fault; BAF, Banning fault; MCF, Mission Creek fault; PMF, Pinto Mountain fault; MVF, Morongo Valley fault; BSZ, Brawley seismic zone. Calibration events are shown as X's. The box encloses the study area shown in following figures.

\section{Relocation Procedure}

Earthquakes occurring between 1932 and 1973 were relocated using station delays calculated from 13 calibration events (Figure 1) and the crustal velocity models of Fuis et al. (1982) (Table 1). The calibration events were earthquakes occurring between 1977 and 1981 that were well located (epicentral precision $\leqq 1 \mathrm{~km}$, depth precision $\pm 2 \mathrm{~km}$ ) using phases from a dense local network, and were of sufficient magnitude (3.0 to 5.5) to be well recorded at regional distances. A modified version of HYPO71 (Lee and Lahr, 1975) was used to initially locate the calibration events and all the steps of the relocation process. Delays for stations at regional distances operating in both the 1977 to 1981 and pre-1973 time periods were estimated by fixing the calibration events at the locations determined by the local network and then comparing theoretical and observed travel times at these regional stations.

The calibration events were divided into two groups: the central Imperial Valley (11 events) and the lower Borrego Valley ( 2 events), based on differences in the 
crustal velocity structure (Table 1) in these regions. Median station delays for the earthquakes in these regions are listed in Table 2.

Although upwards of eight seismograph stations have been operating in southern California since the late 1930's, stations beyond Riverside (RVR) $(>200 \mathrm{~km}$ ) had emergent $P$ arrivals with delays of $>4$ sec and were not used in the relocation process. Tucson (TUO), at a distance of $>400 \mathrm{~km}$ from the Imperial Valley, however, had a consistent delay for all calibration events and was used in the relocations.

TABLE 1

\begin{tabular}{|c|c|c|c|}
\hline \multicolumn{2}{|c|}{ Central Imperial Valley } & \multicolumn{2}{|c|}{ Lower Borrego Valley } \\
\hline $\begin{array}{c}P \text {-Wave Velocity } \\
(\mathrm{km} / \mathrm{sec})\end{array}$ & $\begin{array}{c}\text { Depth to Top of } \\
\text { Layer }(\mathrm{km})\end{array}$ & $\begin{array}{c}\begin{array}{c}P \text {-Wave Velocity } \\
(\mathrm{km} / \mathrm{sec})\end{array} \\
\end{array}$ & $\begin{array}{c}\text { Depth to Top of } \\
\text { Layer }(\mathrm{km}) \\
\end{array}$ \\
\hline 2.0 & 0.0 & 1.8 & 0.0 \\
\hline 2.5 & 1.0 & 2.0 & 0.5 \\
\hline 3.0 & 1.8 & 3.75 & 1.5 \\
\hline 3.5 & 2.3 & 5.5 & 2.0 \\
\hline 4.0 & 3.0 & 5.7 & 2.2 \\
\hline 4.5 & 3.85 & 6.0 & 4.7 \\
\hline 5.0 & 4.15 & 6.5 & 11.7 \\
\hline 5.5 & 5.1 & 7.0 & 12.3 \\
\hline 5.8 & 6.0 & 7.2 & 13.7 \\
\hline 6.0 & 7.0 & 7.5 & 16.0 \\
\hline 6.3 & 8.0 & & \\
\hline 6.6 & 9.5 & & \\
\hline 7.0 & 11.5 & & \\
\hline 7.5 & 14.5 & & \\
\hline
\end{tabular}

TABLE 2

STATION INFORMATION

\begin{tabular}{lccccl}
\hline \multirow{2}{*}{ Station } & \multirow{2}{*}{ Location } & & \multicolumn{2}{c}{ Delay (sec) } & \multicolumn{1}{c}{ Years of Operation } \\
\cline { 4 - 5 } & & & CIV Model & LBV Model & \\
\hline BAR & $32.6800 \mathrm{~N}$ & $116.6717 \mathrm{~W}$ & 0.83 & 0.77 & $1 / 17 / 52$-present \\
GLA & $33.0525 \mathrm{~N}$ & $114.8265 \mathrm{~W}$ & 0.50 & 0.48 & $12 / 20 / 66$-present \\
HAY & $33.7083 \mathrm{~N}$ & $115.6383 \mathrm{~W}$ & 0.50 & 0.52 & $6 / 20 / 56$-present \\
LJC & $32.8633 \mathrm{~N}$ & $117.2533 \mathrm{~W}$ & 0.90 & 0.40 & $5 / 4 / 27-11 / 30 / 75$ \\
PLM & $33.3534 \mathrm{~N}$ & $116.8617 \mathrm{~W}$ & 1.04 & 0.50 & $9 / 7 / 39$-present \\
RVR & $33.9933 \mathrm{~N}$ & $117.3750 \mathrm{~W}$ & 0.47 & 0.45 & $10 / 19 / 26$-present \\
PEC & $33.8919 \mathrm{~N}$ & $117.1607 \mathrm{~W}$ & 0.44 & - & $1950-1951,1 / 1970$-present \\
TUO & $32.2467 \mathrm{~N}$ & $110.8350 \mathrm{~W}$ & -2.26 & -2.26 & 1909 -present \\
\hline
\end{tabular}

The abbreviations used are: CIV, Central Imperial Valley; LBV, Lower Borrego Valley.

Delays were also estimated for LJC (La Jolla) (a station not in current operation, but essential for relocating pre-1939 earthquakes) by estimating delays to CPE (Camp Elliot), a presently operating station $14 \mathrm{~km}$ east of $\mathrm{LJC}$, and allowing for a travel-time difference of $1.9 \mathrm{sec}$, the average difference in theoretical travel times between stations.

Relocations for all earthquakes with $M \geqq 4.5$ listed in the Caltech catalog occurring between 1932 and 1 April 1973 in the region bounded by $115^{\circ} 05^{\prime} \mathrm{W}$ to $116^{\circ} \mathrm{W}$ and $32^{\circ} 25^{\prime} \mathrm{N}$ to $33^{\circ} 35^{\prime} \mathrm{N}$ were attempted using phase information from the Caltech phase card collection. It was felt that most earthquakes with $M_{L} \geqq 4.5$ would be well recorded by the regional network based on the observation that most $M_{L} \geqq 4.5$ 
earthquakes occurring since 1973 have been well recorded at regional distances. This was generally the case except for earthquakes in swarm sequences or aftershock sequences where $M_{L} \geqq 4.5$ events sometimes obscured the $P$ arrival of the larger event. Earthquakes of this size were often felt in some communities in the Imperial Valley and were noted as felt in the phase card collection. These felt reports were then compared with relocated epicenters to see if they were consistent.

Both $P$ and $S$ phases were used to relocate earthquakes between 1932 and 1973 , with the $S$ arrival weighted half the weight of the corresponding $P$ arrival. Arrivals were also weighted by epicentral distance. A weight of one was assigned to arrivals at epicentral distances less than $150 \mathrm{~km}$ and weights decreased linearly between 150 and $500 \mathrm{~km}$ to 0 at $500 \mathrm{~km}$. Since the nearest station in most relocations was over $50 \mathrm{~km}$ away and did not allow for accurate focal depth determination, focal depths were fixed at $7.5 \mathrm{~km}$, the average focal depth in the Imperial Valley (Doser and Kanamori, 1985). Earthquakes with catalog locations east of $115^{\circ} 50^{\prime} \mathrm{W}$ were relocated using the central Imperial Valley delays. The relocations were started at a trial hypocenter located at a point in the center of the area spanned by the calibration events of this region. Similarly earthquakes with catalog locations to the west of $115^{\circ} 50^{\prime} \mathrm{W}$ were relocated using the lower Borrego Valley station delays and a trial hypocenter midway between the calibration events of this region.

TABLE 3

Estimated Resolution of EARTHQUake EPICENTERS

\begin{tabular}{ccc}
\hline Years & $\begin{array}{c}\text { East-West Resolution } \\
(\mathbf{k m})\end{array}$ & $\begin{array}{c}\text { North-South Resolution } \\
(\mathbf{k m})\end{array}$ \\
\hline $1932-1939$ & $15-20$ & $10-15$ \\
$1939-1950$ & $10-15$ & $5-7$ \\
$1950-1952$ & $5-7$ & $3-5$ \\
$1952-1956$ & 5 & $2-3$ \\
$1956-1966$ & 3 & 2 \\
$1966-1973$ & $2-3$ & $1-2$ \\
$1973-1984$ & $1-2$ & 1 \\
\hline
\end{tabular}

Relocations with $\mathrm{rms} \geqq 0.3 \mathrm{sec}$ were rejected. The relocated epicenters of $M_{L} \geqq$ 4.5 events were also compared with any immediate aftershock $(<48 \mathrm{hr}$ after the mainshock) and foreshock locations, and felt reports. Mainshocks located $30 \mathrm{~km}$ or more from immediate aftershock/foreshock locations and felt reports were rejected.

A total of 75 earthquakes of $M_{L} \geqq 4.5$ occurred in the study area from 1932 to 1973. Of this total, 34 lacked sufficient data for relocation or were rejected for poor rms errors. Only three earthquakes were rejected for poor correlations with aftershock/foreshock locations and felt reports, and 2 of the 3 earthquakes occurred prior to 1940 when station coverage was minimal. A total of 105 foreshocks and aftershocks were also relocated. Until the mid-1950's, the smallest magnitude events that could be located had a $M_{L}$ of 3.0 to 3.5 . From the mid-1950's to 1973, earthquakes with $M_{L}=2.5$ could often be relocated.

Tests of the resolution of the relocation process were made by relocating the calibration events using only regional phases. The number of stations used to relocate the calibration events was varied to correspond to the station coverage for different time periods between 1932 and 1973 as indicated in Table 3 . Another test was made by fixing a selected earthquake epicenter at $5^{\prime}$ intervals on a grid between $115^{\circ} 15^{\prime} \mathrm{W}$ and $116^{\circ} 00^{\prime} \mathrm{W}$ and $32^{\circ} 30^{\prime} \mathrm{N}$ and $33^{\circ} 15^{\prime} \mathrm{N}$ and examining theoretical $P$ 
and $S-P$ travel time differences between stations. The estimated resolution for each time period is listed in Table 3. Note that the east-west resolution is always poorer than that in the north-south direction due to the azimuthal distribution of stations prior to 1973.

Epicenters of relocated $M_{L} \geqq 4.5$ earthquakes from 1932 to 1973 and associated foreshocks and aftershocks are shown in Figure 2. Figure 3 shows the catalog locations for all $M_{L} \geqq 4.5$ events from 1932 to 1984 . Table 4 lists the catalog epicenters for all $M_{L} \geqq 4.5$ earthquakes from 1932 to 1973 as well as the epicenters for earthquakes that were successfully relocated (Figure 2).

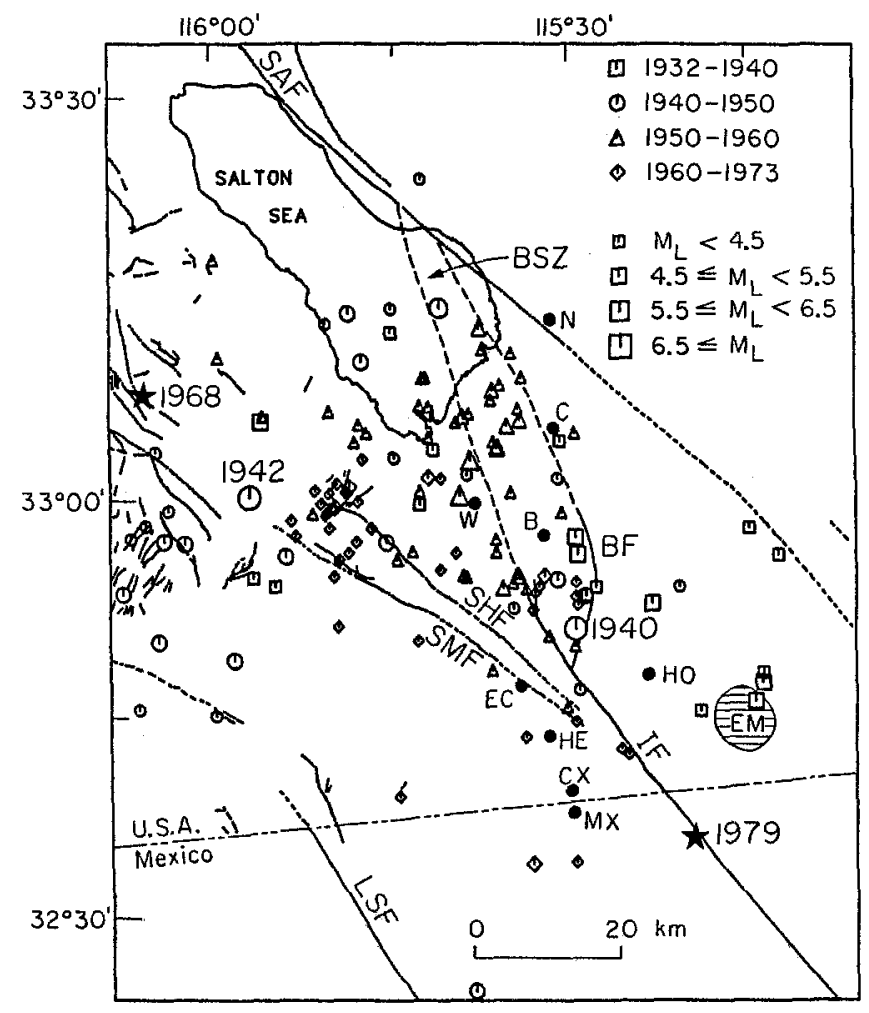

FIG. 2. Relocated earthquakes from 1932-1973. On this and following figures, cities and towns are shown as dots..N, Niland; C, Calipatria; W, Westmorland; B, Brawley; HO, Holtville; EC, El Centro; HE, Heber; CX, Calexico; MX, Mexicali. $M>6.0$ earthquakes are labeled. The 1968 and 1979 earthquakes, not relocated in this study, are denoted by stars. The East Mesa geothermal area is the region labeled EM. The shapes of the symbols are related to the time period in which the earthquakes occurred as indicated. The size of the symbols is related to earthquake magnitude as indicated.

A comparison of relocated epicenters to catalog epicenters shows that relocation tended to spread out earthquake clusters that were listed in the catalog as occurring in the same place. In a few cases, it appeared that $M_{L} \geqq 4.5$ earthquakes occurring within a month or two of another such event were listed in the catalog at the same location as the earlier event, when they probably occurred 20 to $25 \mathrm{~km}$ away. However, most relocated earthquakes were within 10 to $15 \mathrm{~km}$ of the catalog location. Relocations for post-1960 earthquakes were within 1 to $3 \mathrm{~km}$ of the catalog locations.

A- and B-quality ( $\mathrm{rms} \leqq 0.30, \mathrm{ERH} \leqq 2.5 \mathrm{~km}, \mathrm{ERZ} \leqq 5 \mathrm{~km}$ ) earthquakes from 
the Caltech catalog for the time period 1 April 1973 to 31 December 1984 are shown in Figure 4. Note that the relocated seismicity between 1932 and 1973 (Figure 2) shows many of the features seen in Figure 4, including the Brawley Seismic Zone, clusters of swarm activity west of Westmorland, and clusters of activity along the northern Superstition Hills and Superstition Mountain faults. Seismicity not seen in Figure 4 (post-1973) includes activity in the southern part of the Salton Sea west of the Brawley Seismic Zone and activity 30 to $40 \mathrm{~km}$ east of El Centro near the East Mesa geothermal area.

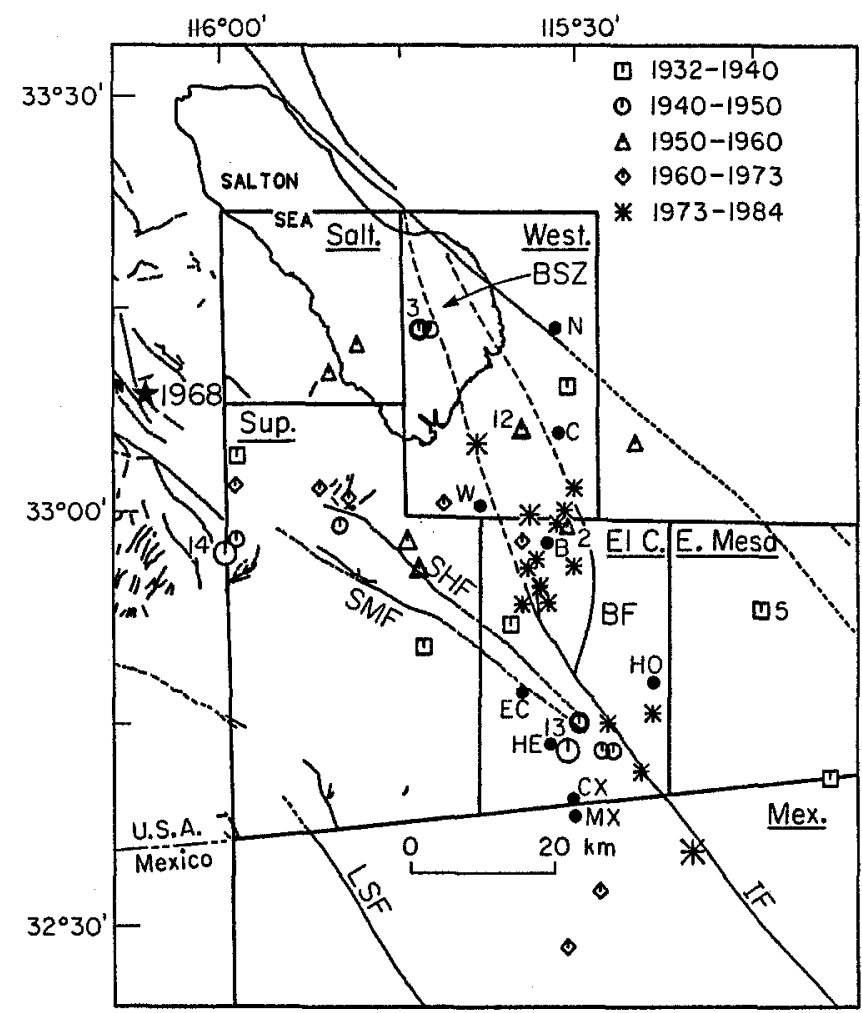

FIG. 3. Caltech catalog locations for earthquakes from 1932 to 1984 with $M_{L} \geqq 4.5$. The symbol shapes are related to the time periods indicated. The symbol size is related to magnitude as in Figure 2 . The numbers beside the symbols indicate the number of earthquakes that were listed in the Caltech catalog as occurring at the location indicated. The study area is divided into six subregions for analyzing the change of moment release through time. The subregions are: Salt, Salton Sea; West., Westmorland; El C., El Centro; E. Mesa, East Mesa; Sup., Superstition Mountain; Mex., Mexico.

\section{Summary of INDIVIDUAL EARTHQUAKE SEQUENCES}

Earthquakes from 1903 to 1932 . Occupation of the Imperial Valley by settlers began between 1901 and 1902 (Cory, 1913) with the first felt earthquake noted in 1902 (Townley and Allen, 1939). Since the historic record for post-1932 $M_{L} \geqq 4.5$ earthquakes appeared to be fairly complete, with most earthquakes of this size having been felt at two or more communities in the Imperial Valley, we chose to study 1902 to 1932 earthquakes with intensities that corresponded to this magnitude range. Using the magnitude-maximum Modified Mercalli intensity $\left(I_{\max }\right)$ scale developed by Topozada (1975), where $M_{L}=1.85+0.49 I_{\max }$, a $M_{L}=4.5$ earthquake 
TABLE 4

EARTHQUAKES IN THE IMPERIAL VALLEY WITH $M_{L} \geqq 4.5$ (1932-1973)

\begin{tabular}{|c|c|c|c|c|}
\hline Date & Origin Time & $\begin{array}{l}\text { Location } \\
\text { (catalog) }\end{array}$ & $\begin{array}{c}\text { Location } \\
\text { (this study)* }\end{array}$ & $\begin{array}{c}\text { Magnitude } \\
\left(M_{L}\right) \\
\end{array}$ \\
\hline $1 / 04 / 34$ & 2153 & $32-42.00115-07.00$ & rms & 4.5 \\
\hline $3 / 02 / 34$ & 2130 & $33-05.00115-59.00$ & $33-07.11115-56.56$ & 4.5 \\
\hline $9 / 08 / 35$ & 1440 & $32-54.00115-13.00$ & $32-57.7511528 .90$ & 4.5 \\
\hline $9 / 08 / 35$ & 1703 & $32-54.00115-13.00$ & $32-58.9611529 .10$ & 5.0 \\
\hline $10 / 11 / 35$ & 1406 & $32-54.00 \quad 115-13.00$ & PCFA & 5.0 \\
\hline $12 / 20 / 35$ & 0745 & $33-10.00115-30.00$ & rms & 5.0 \\
\hline $4 / 07 / 36$ & 2253 & $32-54.00115-13.00$ & PCFA & 4.5 \\
\hline $9 / 18 / 36$ & 1440 & $32-51.36115-42.62$ & rms & 4.5 \\
\hline $4 / 13 / 38$ & 1929 & $32-53.00115-35.00$ & $32-54.23115-22.38$ & 4.5 \\
\hline $6 / 06 / 38$ & 0242 & $32-54.00115-13.00$ & rms & 5.0 \\
\hline $5 / 19 / 40$ & 0436 & $32-44.00115-30.00$ & $32-52.42115-29.08$ & 6.7 \\
\hline $5 / 19 / 40$ & 0448 & $32-46.00115-29.00$ & $\mathrm{rms}$ & 4.5 \\
\hline $5 / 19 / 40$ & 0455 & $32-46.00115-29.00$ & rms & 5.5 \\
\hline $5 / 19 / 40$ & 0504 & $32-46.00115-29.00$ & rms & 4.5 \\
\hline $5 / 19 / 40$ & 0544 & $32-46.00115-29.00$ & $32-54.81115-28.27$ & 4.5 \\
\hline $5 / 19 / 40$ & 0551 & $32-46.00115-29.00$ & rms & 5.5 \\
\hline $5 / 19 / 40$ & 0557 & $32-46.00115-29.00$ & $\mathrm{rms}$ & 4.5 \\
\hline $5 / 19 / 40$ & 0617 & $32-46.00115-29.00$ & rms & 4.5 \\
\hline $5 / 19 / 40$ & 0633 & $32-46.00115-29.00$ & $32-55.95$ 115-30.72 & 5.0 \\
\hline $5 / 19 / 40$ & 0635 & $32-46.00115-29.00$ & $\mathrm{rms}$ & 5.5 \\
\hline $5 / 19 / 40$ & 0701 & $32-46.00115-29.00$ & $\mathrm{rms}$ & 4.5 \\
\hline $5 / 19 / 40$ & 1530 & $32-46.00115-29.00$ & $32-26.43115-38.02$ & 4.5 \\
\hline $5 / 22 / 40$ & 1058 & $32-46.00115-29.00$ & $\mathrm{rms}$ & 4.5 \\
\hline $6 / 01 / 40$ & 2359 & $32-46.00115-29.00$ & $\mathrm{rms}$ & 4.5 \\
\hline $7 / 22 / 41$ & 1852 & $32-44.00115-27.00$ & $\mathrm{rms}$ & 4.5 \\
\hline $5 / 23 / 42$ & 1547 & $32-59.00115-59.00$ & IDFL & 5.0 \\
\hline $10 / 21 / 42$ & 1622 & $32-58.00116-00.00$ & $33-01.75115-57.67$ & 6.5 \\
\hline $10 / 21 / 42$ & 1625 & $32-58.00116-00.00$ & $32-58.59115-45.64$ & 5.0 \\
\hline $10 / 21 / 42$ & 1626 & $32-58.00116-00.00$ & $32.54 .80116-08.71$ & 5.0 \\
\hline $10 / 21 / 42$ & 1634 & $32-58.00116-00.00$ & $32-51.39116-05.51$ & 4.5 \\
\hline $10 / 21 / 42$ & 1638 & $32-58.00116-00.00$ & $32-50.11 \quad 115-58.93$ & 4.5 \\
\hline $10 / 21 / 42$ & 1910 & $32-58.00116-00.00$ & rms & 4.5 \\
\hline $10 / 21 / 42$ & 2149 & $32-58.00116-00.00$ & $32-58.76116-08.02$ & 4.5 \\
\hline $10 / 22 / 42$ & 0150 & $33-14.00115-43.00$ & $33-15.25 \quad 115-40.94$ & 5.5 \\
\hline $10 / 22 / 42$ & 1813 & $32-58.00116-00.00$ & $\mathrm{rms}$ & 5.0 \\
\hline $10 / 26 / 42$ & 0302 & $33-14.00115-43.00$ & $33-14.03115-50.95$ & 4.5 \\
\hline $10 / 26 / 41$ & 0615 & $33-14.00115 .43 .00$ & $33-14.81115-48.96$ & 4.5 \\
\hline $10 / 29 / 42$ & 1556 & $32-58.00116-00.00$ & $32-58.60116-05.12$ & 4.5 \\
\hline $10 / 29 / 42$ & 1621 & $32-58.00116 .00 .00$ & $\mathrm{rms}$ & 4.5 \\
\hline $10 / 30 / 42$ & 0535 & $32-58.00116-00.00$ & rms & 4.5 \\
\hline $11 / 02 / 42$ & 1259 & $32-58.00116-00.00$ & $32.58 .44116-03.30$ & 4.5 \\
\hline $11 / 03 / 42$ & 0506 & $32-58.00116-00.00$ & $32-57.56115-54.42$ & 4.5 \\
\hline $3 / 17 / 43$ & 0040 & $32-44.00115-26.00$ & $32-48.03115-28.83$ & 4.5 \\
\hline $11 / 02 / 43$ & 1647 & $32-58.00116-00.00$ & $\mathbf{r m s}$ & 4.5 \\
\hline $11 / 02 / 43$ & 1750 & $32-58.00116-00.00$ & rms & 4.5 \\
\hline $1 / 08 / 46$ & 1854 & $33-00.00115-50.00$ & rms & 5.4 \\
\hline $8 / 30 / 46$ & 1116 & $33-14.00115-42.00$ & $33-11.38115-47.83$ & 4.6 \\
\hline $7 / 27 / 50$ & 1129 & $33-07.00115-34.00$ & $33-07.28115-33.82$ & 4.8 \\
\hline $7 / 27 / 50$ & 2251 & $33-07.00115-34.00$ & $33-05.22$ 115-35.95 & 4.5 \\
\hline $7 / 28 / 50$ & 0325 & $33-07.00115-34.00$ & $33-06.85115-35.00$ & 4.7 \\
\hline $7 / 28 / 50$ & 1727 & $33-07.00115-34.00$ & $33-13.80115-37.45$ & 4.7 \\
\hline $7 / 28 / 50$ & 1750 & $33-07.00115-34.00$ & $33-07.56$ 115-38.89 & 5.4 \\
\hline $7 / 28 / 50$ & 1758 & $33-07.00115-34.00$ & $\mathbf{r m s}$ & 4.8 \\
\hline $7 / 29 / 50$ & 0017 & $33-07.00115-34.00$ & rms & 4.5 \\
\hline $7 / 29 / 50$ & 1436 & $33-07.00115-34.00$ & $33-04.42115-38.28$ & 5.5 \\
\hline
\end{tabular}


TABLE 4-Continued

\begin{tabular}{rcclc}
\multicolumn{1}{c}{ Date } & Origin Time & \multicolumn{1}{c}{$\begin{array}{c}\text { Location } \\
\text { (catalog) }\end{array}$} & \multicolumn{1}{c}{$\begin{array}{c}\text { Location } \\
\text { (this study) }\end{array}$} & $\begin{array}{c}\text { Magnitude } \\
\left(M_{L}\right)\end{array}$ \\
\hline $7 / 29 / 50$ & 1509 & $33-07.00115-34.00$ & rms & 4.5 \\
$7 / 29 / 50$ & 1843 & $33-07.00115-34.00$ & $33-09.37115-36.27$ & 4.7 \\
$8 / 01 / 50$ & 0837 & $33-07.00115-34.00$ & rms & 4.7 \\
$8 / 14 / 50$ & 1916 & $33-07.00115-34.00$ & rms & 4.7 \\
$1 / 24 / 51$ & 0717 & $32-59.00115-44.00$ & $33-01.93115-39.26$ & 5.6 \\
$12 / 05 / 51$ & 1553 & $33-06.00115-24.00$ & rms & 4.5 \\
$6 / 14 / 53$ & 0417 & $32-57.00115-43.00$ & PCFA & 5.5 \\
$6 / 14 / 53$ & 0429 & $32-57.00115-43.00$ & rms & 4.8 \\
$12 / 17 / 55$ & 0607 & $33-00.00115-30.00$ & $32-55.33115-35.44$ & 5.4 \\
$12 / 17 / 55$ & 0652 & $33-00.00115-30.00$ & $32-56.16115-34.03$ & 4.6 \\
$4 / 25 / 57$ & 2157 & $33-12.99115-48.50$ & $33-05.35115-35.84$ & 5.2 \\
$4 / 25 / 57$ & 2224 & $33-11.00115-51.00$ & rms & 5.1 \\
$5 / 26 / 57$ & 1559 & $33-13.88116-00.27$ & rms & 5.0 \\
$2 / 09 / 61$ & 1750 & $32-30.00115-30.00$ & rms & 4.8 \\
$9 / 12 / 61$ & 1918 & $32-34.02115-27.15$ & $32-35.50115-32.88$ & 4.8 \\
$5 / 23 / 63$ & 0906 & $33-01.63115-40.87$ & $32-56.20115-31.83$ & 4.6 \\
$5 / 23 / 63$ & 1553 & $33-01.63115-40.87$ & $33-03.18115-41.94$ & 4.8 \\
$4 / 16 / 68$ & 0330 & $33-02.88115-59.16$ & rms & 4.8 \\
$12 / 17 / 68$ & 2253 & $33-02.69115-51.79$ & $33-01.03115-50.15$ & 4.7 \\
$9 / 30 / 71$ & 2246 & $33-02.01115-49.24$ & $33-02.49115-48.90$ & 5.1 \\
\hline
\end{tabular}

* rms > 0.30; IDFL, insufficient data for location; PCFA, poor correlation with foreshocks, aftershocks, and felt area.

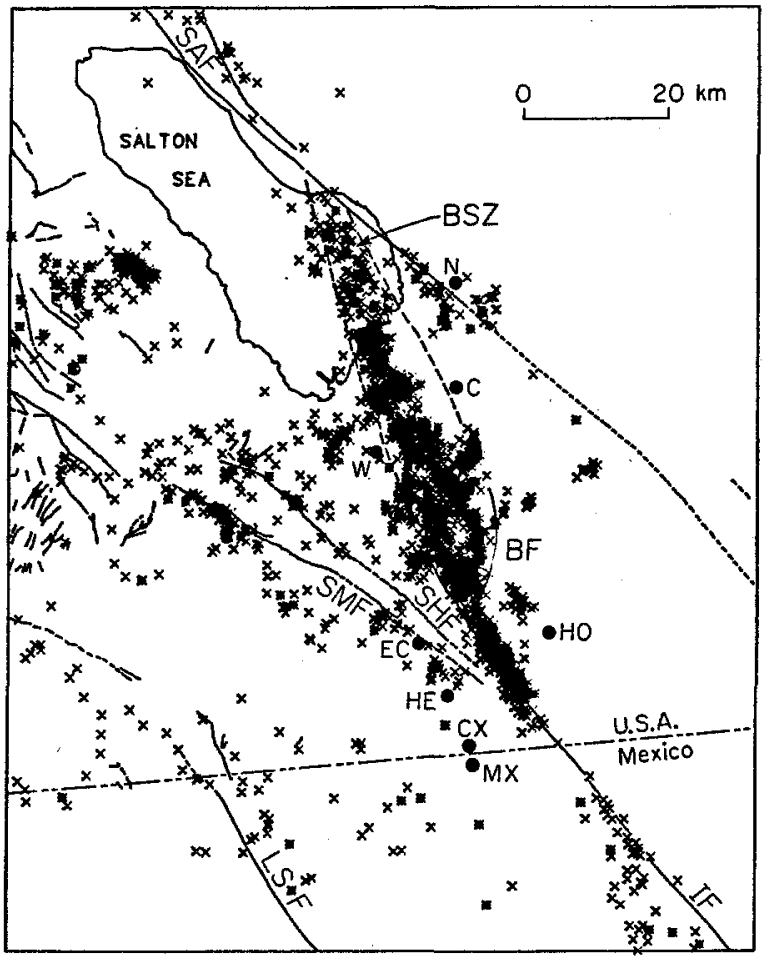

FIG. 4. A- and B-quality earthquakes (1973-1984) from the Caltech catalog. The symbol shape denotes earthquake size. X's, $M_{L}<3.0$; 's, $3.0 \leqq M_{L}<4.0$; circles, $4.0 \leqq M_{L}<5.0$. 
corresponds to a Modified Mercalli intensity of V+ or a Rossi-Forrel intensity of about VI+. Earthquakes with Modified Mercalli intensities of $>V$ or Rossi-Forrel intensities of $>$ VI are listed in Table 5 and their locations are shown in Figure 5. The magnitudes listed in Table 5 are either instrumental magnitudes (Gutenberg and Richter, 1949; Richter, 1958) or magnitudes estimated from maximum intensity, size of felt area, instrumental amplitude, and/or radius of isoseismal lines (Topozada et al., 1978). Although the 8 September 1921 and 2 October 1928 earthquakes listed in Table 5 did not have intensity $>V$ (from now on intensity will refer to Modified Mercalli intensity), they were included because their instrumental magnitudes were greater than 4.5.

TABLE 5

EARTHQUakes WITH Modified MERCALLI INTENSITY > V (1901-1932)

\begin{tabular}{|c|c|c|c|c|}
\hline Date & $\begin{array}{c}\text { Modified Mercalli } \\
\text { Intensity* }\end{array}$ & $M$ & $\begin{array}{c}\text { Location of } \\
\text { Maximum Intensity } \dagger \\
\end{array}$ & Referencet \\
\hline $4 / 19 / 06(0030)$ & VIII & 6.0 & Brawley (32-30 115-30) & $1,3,3$ \\
\hline $6 / 23 / 15(0359)$ & VIII & 6.3 & El Centro (32-48 115-30) & $1,3,3$ \\
\hline $6 / 23 / 15(0456)$ & VIII & 6.3 & El Centro (32-48 115-30) & $1,3,3$ \\
\hline $5 / 28 / 17(0606)$ & VII & 5.5 & Holtville (32-48 115-18) & $5,4,4$ \\
\hline $5 / 01 / 18(0432)$ & VI & 5.0 & Calexico $(32-30$ 115-30) & $1,4,1$ \\
\hline $12 / 20 / 20(1447)$ & VI & 4.5 & Brawley (33-00 115-30) & $5,4,4$ \\
\hline $12 / 21 / 20(1452)$ & VI & 4.5 & Brawley (33-00 115-30) & $5,4,4$ \\
\hline $9 / 08 / 21(1924)$ & IV & 5.0 & Calexico $(32-30$ 115-30) & $5,4,1$ \\
\hline $11 / 05 / 23(2207)$ & VII & 5.0 & Calexico $(32-30$ 115-30) & $1,4,1$ \\
\hline $11 / 07 / 23(2357)$ & VII & 5.5 & Baja, California (32-30 115-30) & $1,4,1$ \\
\hline $4 / 16 / 25(0330)$ & VI & $?$ & Calexico $(32-30115-30)$ & $1,-, 1$ \\
\hline $4 / 16 / 25(0520)$ & VI & $?$ & Calexico $(32-30$ 115-30) & $5,-, 4$ \\
\hline $1 / 01 / 27(0816)$ & VIII & 5.8 & Mexicali (32-30 115-30) & $1,2,1$ \\
\hline $1 / 01 / 27(0913)$ & VIII & 5.5 & Calexico $(32-30$ 115-30) & $1,2,1$ \\
\hline $1 / 01 / 27(1300)$ & VI & $?$ & Calexico (32-42 115-30) & $5,-, 4$ \\
\hline $10 / 02 / 28(1901)$ & $?$ & 5.0 & Superstition Mountain (32-54 115-42) & $-, 4,4$ \\
\hline $2 / 26 / 30(0230)$ & VIII & 5.0 & Westmorland (33-00 115-30) & $1,1,1$ \\
\hline $3 / 01 / 30(2305)$ & VI & 4.5 & Brawley (33-00 115-30) & $4,2,4$ \\
\hline $3 / 01 / 30(2344)$ & VIII & 4.5 & Brawley (33-00 115-30) & $1,1,1$ \\
\hline
\end{tabular}

* Rossi-Forel intensities have been converted to Modified Mercalli intensities using conversion outlined in Topozada et al. (1978).

$\dagger$ City or region where maximum intensity was felt. Epicenter location is in parentheses.

¥ First number is intensity reference, second is magnitude reference, and third is location reference. 1, Coffmann and von Hake (1973); 2, Gutenberg and Richter (1949); 3, Richter (1958); 4, Topozada et al. (1978); 5, Townley and Allen (1939).

The earliest earthquake in the Imperial Valley with intensity $>V$ occurred in 1906. Although the instrumental epicenter of Richter (1958) places the earthquake south of the border, intensity reports compiled by Topozada and Parke (1982) show that significant damage occurred in Brawley, and that most communities to the south suffered little damage. This suggests the earthquake may have occurred near Brawley or Westmorland. Therefore, the 1906 earthquake may represent the main event of a swarm sequence similar to ones that have been recorded near Brawley in 1955,1963 , and 1975 with main events of $M_{L} 5.5$ to 5.7 .

In 1915, a sequence of two earthquakes with intensity VIII occurred $1 \mathrm{hr}$ apart in the southern part of the Imperial Valley. Twenty minutes before the first shock, a foreshock was felt (Beal, 1915). Intensity reports for the two main events were 
similar, and buildings were severely damaged in El Centro, Heber, Calexico, and Mexicali (Beal, 1915), suggesting that the earthquakes may have occurred along the Imperial fault. No surface faulting or offset of irrigation canals was observed during this sequence.

Since the 1915 earthquakes had magnitudes within 0.3 magnitude units of the Imperial Valley earthquake of 1979, a comparison of intensity maps is shown in Figure 6. Isoseismals for the 1915 earthquakes are skewed in a northwest-southeast direction relative to the 1979 isoseismals due to intensity differences at Brawley and Holtville. Differences in building construction between these time periods may contribute to the intensity differences as well as the fact that the timing of the 1915

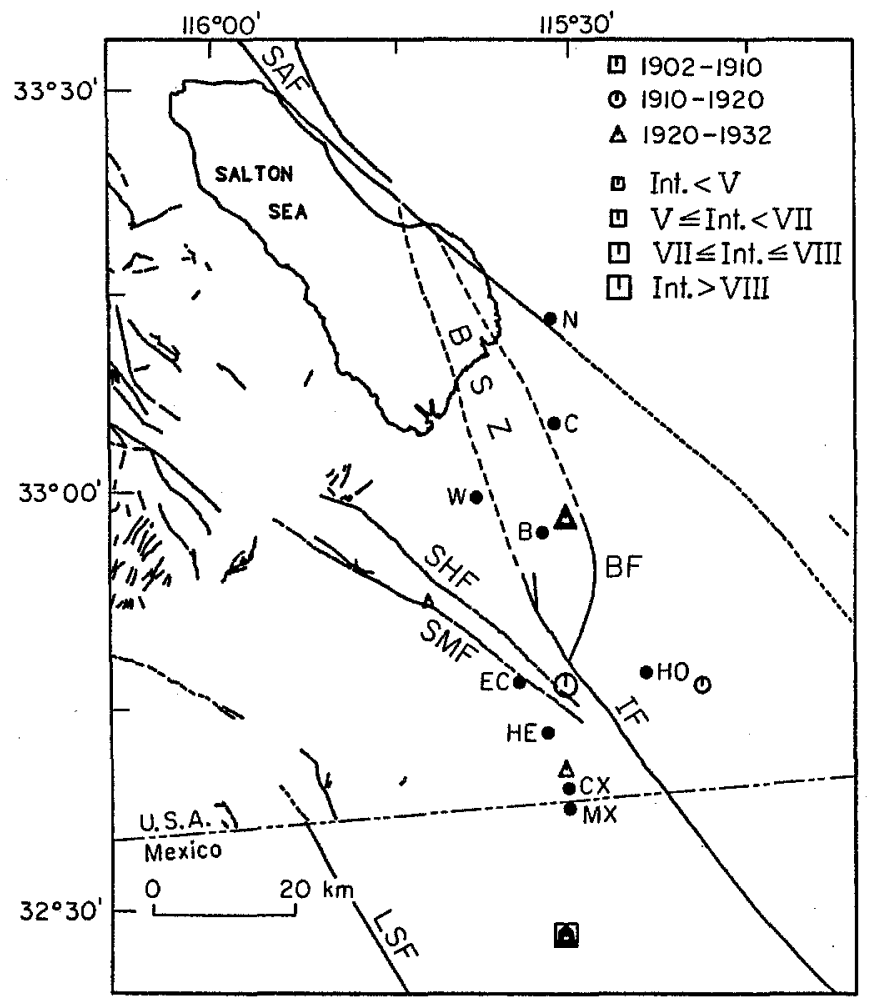

FIG. 5. Locations of earthquakes occurring in the Imperial Valley between 1902 and 1932 from Coffman and von Hake (1973), Topozada et al. (1978), and Richter (1958). The symbol shapes and sizes denote time period and Modified Mercalli intensity.

shocks made it impossible to separate the damage caused by the individual events. In 1979, no felt foreshocks were observed, and within $8 \mathrm{hr}$ of the mainshock, an aftershock with $M_{L}=5.8$ occurred near Brawley causing additional damage. This pattern of no felt foreshocks and a large damaging aftershock near Brawley was not seen in 1915, but was seen during the 1940 earthquake sequence along the Imperial fault.

The 1915 isoseismals suggest the epicenters were located to the west of the Imperial fault in a region along the inferred extensions of the Superstition Hills and Superstition Mountain faults. The only area southwest of the Imperial fault that shows evidence of recent tectonic movement is near Dixieland (Figure 6) where $4.5 \mathrm{~mm} / \mathrm{yr}$ of creep from 1970 to 1974 has been measured along ground cracks first 
observed in 1970 (Louie et al., 1985). The low intensity (<VI) reported at Dixieland and Seeley in 1915 would tend to rule out this fault as the causative structure. Trenching along the Imperial fault $10 \mathrm{~km}$ east of Calexico has shown no evidence for offset along the fault for $700 \mathrm{yr}$ prior to 1940 (Clark et al., 1984). The 1915 earthquakes are in the magnitude range where they may not have produced surface offsets; although many small earthquakes in the Imperial Valley [as small as $M_{L}=$ 3.6 (Brune and Allen, 1967)] have produced surface displacements.

It is important to note that no matter which fault or faults ruptured during the 1915 sequence, surface displacement was either nonexistent or of such an amount to have not been recognized. This suggests that it may be difficult to use surficial geology to determine which faults in the Imperial Valley region are capable of producing magnitude 6 to 6.5 earthquakes.

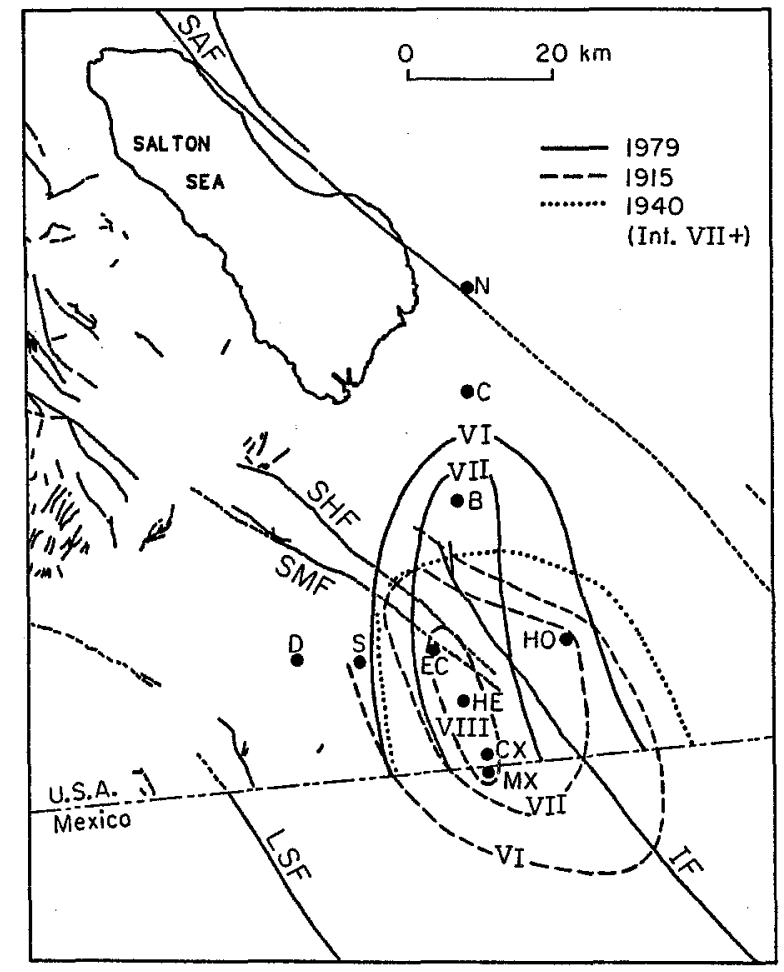

FIG. 6. Isoseismals for the 1915, 1940, and 1979 earthquakes modified from Beal (1915), Ulrich (1941), and Reagor et al. (1982). The 1940 isoseismal surrounds the intensity VII+ region for the mainshock. D, Dixieland; S, Seeley.

In 1917, a $M_{L}=5.5$ earthquake occurred near Holtville with highest intensities reported in open country $13 \mathrm{~km}$ southeast of town. This places the earthquake in the same region as relocated epicenters for earthquakes in 1934 and 1938, suggesting that the area was seismically active for at least $23 \mathrm{yr}$ prior to the 1940 earthquake.

A number of earthquakes have been reported to have occurred south or near Calexico, although the region was sparsely populated and some intensity $>V$ events may not have been detected. Intensities for events in this region were generally based on felt reports at Calexico or Mexicali and may represent underestimates of maximum intensity. Between 1918 and 1932, at least five sequences with intensity $>\mathrm{V}$ or $M>5.0$ mainshocks occurred. Timing errors for $P$ and $S$ arrivals from the 
ISS (International Seismological Summary) at regional distances (400 to $2000 \mathrm{~km}$ ) for the 1927 sequence were too great to obtain reliable relocations.

A maximum intensity was not assigned to the 1928 Superstition Mountain earthquake due to its location in a sparsely populated area, although Topozada et al. (1978) give it a magnitude of about 5.0. It occurs in a region $25 \mathrm{~km}$ southeast of the 1942 Superstition Mountain earthquake.

Earthquake sequences occurred near Brawley and Westmorland in 1920 and 1930. Phase data were listed in the ISS for the two highest intensity events of the 1930 sequence, but timing errors again were too great to allow accurate locations. The intensity reports of these events suggest that they were part of a swarm sequence similar to sequences occurring in 1951, 1955, and 1963.

Earthquakes from 1932 to 1984 . Between 1934 and 1938, a series of earthquakes occurred in the region southeast of the Imperial fault. Although some of the events were reported as felt in El Centro or Brawley and may have occurred along the Imperial fault, felt reports for sequences occurring in 1934 and 1936 (relocated directly east of El Centro and $30 \mathrm{~km}$ east of Brawley) suggest that the relocations in Figure 2 are accurate.

The largest earthquake to have occurred in the region since 1902 was the 19 May 1940 event. Relocations of the mainshock and aftershocks have been previously discussed in Doser and Kanamori (1985). The mainshock is located $10 \mathrm{~km}$ northwest of Richter's (1958) instrumental epicenter and just to the northwest of the portion of the Imperial fault that showed greatest slip during the 1979 earthquake, suggesting that both the 1940 and 1979 earthquakes ruptured the same part of the fault, although the direction of rupture propagation in the events was $180^{\circ}$ apart. The displacements in 1940 and 1979 on the segment of the fault located north of the border were also similar (Sharp, 1982).

The intensity pattern for the mainshock is shown in Figure 6. Note that it has been modified from Ulrich (1941) to exclude the effects of a $M_{L}=5.8$ aftershock located near Brawley that had an intensity of IX, whereas the mainshock only had an intensity of VII at this location. The shape of the isoseismals is similar to that of the 1979 earthquake.

In 1942, a $M_{L}=6.5$ event occurred at the western edge of Imperial Valley. The catalog location placed the epicenter at $32^{\circ} 58^{\prime} \mathrm{N} 116^{\circ} \mathrm{W}$, a location at the edge of the study area. Several unrelocated aftershocks were east of this location, and so the mainshock was relocated. The relocated mainshock lies to the northwest of both the Superstition Hills and Superstition Mountain faults at $33^{\circ} 01.7^{\prime} \mathrm{N}, 115^{\circ} 57.7^{\prime} \mathrm{W}$. Sanders (personal communication, 1985) has relocated the 1942 earthquake at $33^{\circ} 01.4^{\prime} \mathrm{N}, 116^{\circ} 03.3^{\prime} \mathrm{W}$ (about $9 \mathrm{~km}$ west of our relocation) using a different velocity model and set of calibration events. His location is within the estimated east-west error bars of $\pm 10 \mathrm{~km}$ for our relocation and lies within the highly fractured region between the ends of the Elsinore and Agua Caliente faults (Figure 1). Since the mainshock occurred in a sparsely populated area, intensity distributions are not helpful in determining the epicenter.

Nine hours after the Superstition Mountain mainshock, a magnitude 5.5 earthquake occurred near Niland about $15 \mathrm{~km}$ from the southern end of the San Andreas fault and $35 \mathrm{~km}$ from the Superstition Mountain event. Magnitude $>4.5$ aftershocks occurred in both the Niland and Superstition Mountain regions as late as 1946.

For $8 \mathrm{yr}$ following the 1942 sequence, the central Imperial Valley and Brawley Seismic zone were relatively quiescent. In 1950, the region experienced increased activity with a series of swarm sequences that began in the central part of the 
Brawley Seismic Zone and continued through 1957. Swarms again occurred near Brawley and Westmorland in 1963.

Following the 1963 swarm sequence, there were several years of quiescence before the 1968 Borrego Mountain earthquake. Aftershocks of the 1968 Borrego Mountain earthquake (Figure 2) extended into the study region along the Superstition Mountain fault. This was followed by a $M_{L}=5.1$ earthquake that occurred near the northern end of the Superstition Mountain fault in a region that was seismically active in 1968.

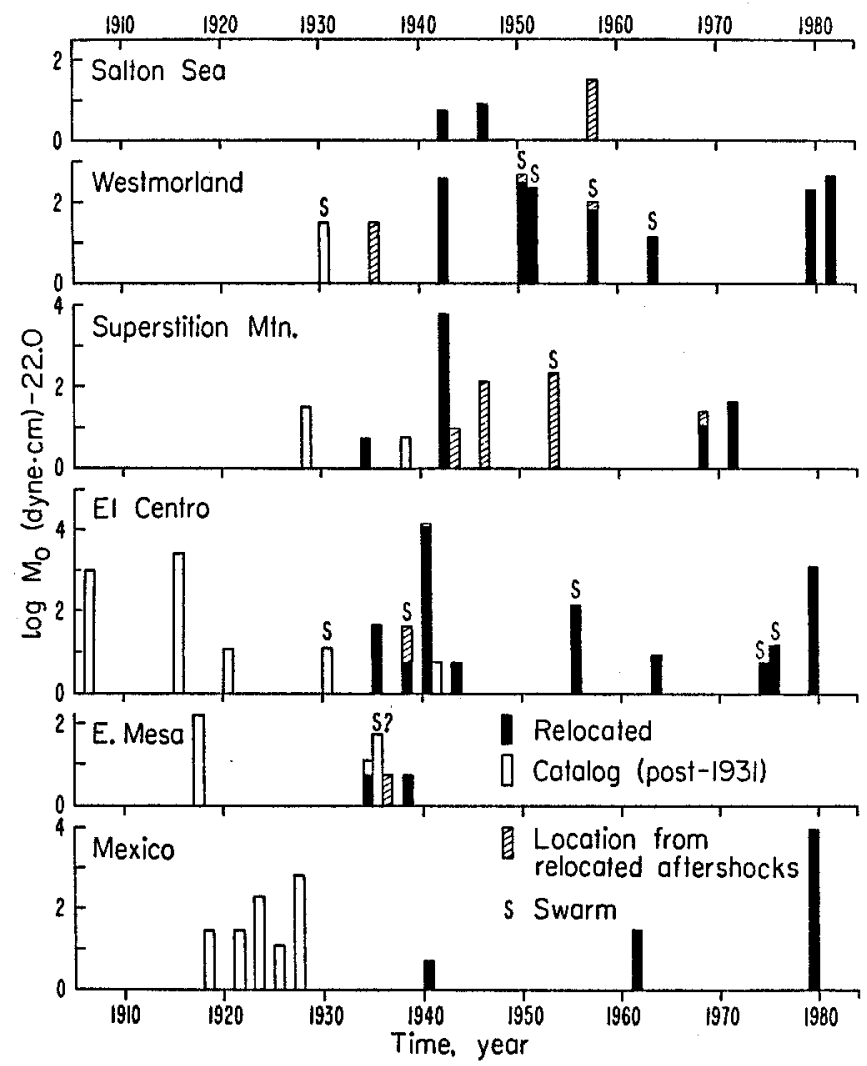

FIG. 7. Moment release through time for the six subregions shown in Figure 3. The unshaded bars represent moments from earthquakes located from intensity reports or from earthquakes from the Caltech catalog prior to 1973 that could not be relocated. The shaded bars represent relocated earthquakes and earthquakes from the catalog occurring after 1973. The striped bars represent earthquakes that could not be relocated and were assumed to have occurred in the same subregion as immediate (less than 48 $\mathrm{hr}$ after the mainshock) aftershocks and/or foreshocks. The " $\mathrm{S}$ " denotes the moment release associated with swarm sequences.

Since 1973, swarms have occurred along the Brawley fault near Brawley and along the Imperial fault between Brawley and El Centro. For 3 months prior to the 1979 mainshock, the area was relatively aseismic (Johnson and Hutton, 1982). Aftershocks of the 1979 earthquake with $M_{L}>4.5$ primarily occurred at the northern end of the Imperial fault. Since 1979 , only one $M_{L} \geqq 4.5$ earthquake has occurred.

\section{Discussion}

The migration of seismicity and variation in moment rate through the Imperial Valley region from 1902 to 1984 are shown in Figure 7. Moment rates and number 
of earthquakes per year are listed in Table 6. The rates were estimated using the relationship $\log M_{0}=16+1.5 M_{L}$ (Thatcher and Hanks, 1973) derived for southern California. In Figure 7, The Imperial Valley region has been divided into six subregions as shown in Figure 3. The subregions were constructed as follows: the El Centro region contains seismicity associated with the Imperial and Brawley faults north of the Mexican border, the Westmorland region contains the northern

TABLE 6

Moment Release in SUbRegions of the Imperial Valley

\begin{tabular}{cllllll}
\hline Year & \multicolumn{1}{c}{$\mathrm{EC}^{*}$} & \multicolumn{1}{c}{ EM } & \multicolumn{1}{c}{ W } & SS & SM & M \\
\hline 1906 & $3.00(1) \dagger$ & - & - & - & - & - \\
1915 & $3.45(2)$ & - & - & - & - & - \\
1917 & - & $2.25(1)$ & - & - & - & - \\
1918 & - & - & - & - & - & $1.5(1)$ \\
1920 & $1.15(2)$ & - & - & - & - & - \\
1921 & - & - & - & - & - & $1.5(1)$ \\
1923 & - & - & - & - & - & $2.3(2)$ \\
1925 & - & - & - & - & - & $1.1(2)$ \\
1927 & - & - & - & - & - & $2.8(3)$ \\
1928 & - & - & - & - & $1.5(1)$ & - \\
1930 & $1.1(2)$ & - & $1.5(1)$ & - & - & - \\
1934 & - & $1.1(2)$ & - & - & $0.75(1)$ & - \\
1935 & $1.6(2)$ & $1.75(1)$ & $1.5(1)$ & - & - & - \\
1936 & - & $0.75(1)$ & - & - & - & - \\
1938 & $1.6(2)$ & $0.75(1)$ & - & - & $0.75(1)$ & - \\
1940 & $4.1(11)$ & - & - & - & - & $0.75(1)$ \\
1942 & $0.75(1)$ & - & $2.6(1)$ & $0.75(1)$ & $3.78(9)$ & - \\
1943 & $0.75(1)$ & - & - & - & $1.0(2)$ & - \\
1946 & - & - & - & $0.90(1)$ & $2.1(1)$ & - \\
1950 & - & - & $2.6(2)$ & - & - & - \\
1951 & - & - & $2.4(2)$ & - & - & - \\
1953 & - & - & - & - & $2.3(2)$ & - \\
1955 & $2.15(2)$ & - & - & - & - & - \\
1957 & - & - & $2.0(2)$ & $1.5(1)$ & - & - \\
1961 & - & - & - & - & - & $1.5(2)$ \\
1963 & $0.9(1)$ & - & $1.2(1)$ & - & - & - \\
1968 & - & - & - & - & $1.4(2)$ & - \\
1971 & - & - & - & - & $1.7(1)$ & - \\
1974 & $0.75(1)$ & - & - & - & - & - \\
1975 & $1.2(1)$ & - & - & - & - & - \\
1979 & $3.4(9)$ & - & $2.3(3)$ & - & - & $3.9(1)$ \\
1981 & - & - & $2.6(1)$ & - & - & - \\
\hline 19 & & - & & - & - & - \\
\hline
\end{tabular}

The abbreviations used are: EC, El Centro; W, Westmorland; SS, Salton Sea; SM, Superstition Mountain; M, Mexico; EM, East Mesa.

* Log (moment, dyne-cm), 22.0.

$\uparrow$ Number of earthquakes is in parentheses.

Brawley Seismic Zone and the region directly west of Westmorland where swarm sequences are prevalent, the Superstition Mountain region contains seismicity near the Superstition Hills and Superstition Mountain faults and aftershocks of the 1942 earthquake, the Salton Sea region contains events along the western shore of Salton Sea, the East Mesa region contains events east of Holtville near the East Mesa geothermal area, and the Mexico region contains events to the south of the border that were felt in Calexico and were either located on the Imperial fault or near Calexico. 
Earthquakes with $M_{L} \geqq 4.5$ occurring within the region are divided into three categories: (1) relocated earthquakes or Caltech catalog post-1973 earthquakes; (2) earthquakes that could not be relocated but were assumed to have occurred near where the relocated aftershocks occurred; and (3) earthquakes that could not be located, had no locatable aftershocks, and were assumed to have occurred at the catalog location (post-1932) or the location of the highest intensity (1902-1932). The earthquakes in Table 5 that did not have magnitudes estimated from other studies were assumed to have $M_{L}=4.5$. All the moment was assumed to have been released in the region where the epicenter was located, instead of dividing the moment release between two regions when a fault rupture crossed regions. Moment release associated with known swarm sequences is labeled by an "S" in Figure 7. Prior to 1930, felt reports were not sufficient to determine which events were associated with swarm sequences.

Patterns seen in Figure 7 that have been noted earlier by Johnson (1979) include: (1) the absence of swarms for $10 \mathrm{yr}$ after the 1940 earthquake; (2) a sudden increase in moment rate associated with the resumption of swarm activity in 1950; and (3) the southward migration of swarm activity between 1950 and 1955 . In addition to patterns noted by Johnson, the following observations were made for the three largest earthquakes to have occurred in the Imperial Valley.

In the $10 \mathrm{yr}$ prior to the 1979 earthquake, one swarm sequence with $M_{L} \geqq 4.5$ events occurred 5 yr prior to the mainshock. Aftershocks (as defined in the introduction) with $M_{L} \geqq 4.5$ occurred only within the first 2 months of the sequence. Two years later, an earthquake sequence with a $M_{L}>4.5$ event occurred in the northern Imperial Valley. Since 1981, there has been noted quiescence along the Brawley Seismic Zone as seen in the catalog data.

In the $10 \mathrm{yr}$ prior to the 1940 earthquake, there were three swarm sequences with $M_{L} \geqq 4.5$ events; one at $10 \mathrm{yr}$ before the mainshock, one at $5 \mathrm{yr}$, and one at $2 \mathrm{yr}$. Aftershocks with $M_{L}>4.5$ also occurred only during the first 2 months of the sequence. Two years after the mainshock, the Superstition Mountain and Niland earthquake sequences occurred. With the exception of aftershocks related to the 1942 sequences, the entire region was quiescent until 1950 when seismicity resumed with swarms along the north-central part of the Brawley Seismic Zone.

It is more difficult to determine whether any swarm sequences occurred prior to the 1915 earthquakes. The 1906 event may have been the largest event of a swarm sequence near Brawley or a single event. The number of felt events for 1910 is 2 to 3 times the yearly average (Wood, 1941) and may represent swarm activity. Unlike the 1979 and 1940 sequences, earthquakes with intensity $>V$ within $30 \mathrm{~km}$ of the 1915 epicenters resumed in 1917 with a series of earthquakes east of Holtville, and in 1918, a 9-yr sequence of intensity $>\mathrm{V}$ events began near Calexico.

These observations suggest that $M_{L}>6.0$ earthquakes in the central Imperial Valley may be preceded by swarm sequences occurring 2 to $5 \mathrm{yr}$ before the mainshock; aftershocks with $M_{L}>4.5$ would occur for only 2 months following the mainshock. The region within $30 \mathrm{~km}$ of the mainshock may remain quiescent at the $M_{L}>4.5$ level for 8 to $10 \mathrm{yr}$ following the mainshock.

In contrast, the 1942 Niland, 1942 Superstition Mountain, and 1968 Borrego Mountain sequences were not preceded by noted swarm sequences and had extensive aftershock sequences with aftershocks of $M_{L} \geqq 4.5$ occurring within $30 \mathrm{~km}$ of the mainshock epicenter for up to 4 or $5 \mathrm{yr}$ after the mainshock. This suggests that the mechanism of strain release prior to and following $M>6.0$ earthquakes varies between the central Imperial Valley and the edges of the valley. The difference may 
be due to elevated heat flow in the central Imperial Valley that would cause rocks to behave differently under stress.

What appears to set the 1940 earthquake apart from the 1979 event is the increase in seismicity in regions surrounding the El Centro region for $15 \mathrm{yr}$ prior to the 1940 event. Intensity $>V$ or $M_{L} \geqq 4.5$ earthquakes occurred in the East Mesa, Mexico, Superstition Mountain, and Westmorland areas during this time period. If the 1915 earthquake did not occur on the Imperial fault, but rather to the west of the fault, then the epicenters of $M_{L} \geqq 4.5$ or intensity $>V$ earthquakes prior to 1940 would nearly encircle the segment of the Imperial fault that ruptured during the 1940 mainshock. Unlike the 1940 earthquake, for $15 \mathrm{yr}$ prior to the 1979 mainshock the only seismically active region at the $M_{L} \geqq 4.5$ level besides El Centro was the Superstition Mountain region, and this seismicity was associated with the 1968 Borrego Mountain earthquake.

Johnson's (1979) study of historical seismicity noted that swarm sequences in the Imperial Valley appeared to be cyclic in nature with a cycle time (time between the end of one swarm and the beginning of the next) of 12 to $13 \mathrm{yr}$. Since 1930, there have been swarm sequences in 1930, 1936 to 1938,1950 to 1957,1963 , and 1974 to 1975 with $M_{L} \geqq 4.5$ events, where swarm sequences are defined as a series of earthquake swarms with $M_{L} \geqq 4.5$ events with periods of less than 3 yr between individual $M_{L} \geqq 4.5$ events. This gives cycle times of $6,12,6$, and $11 \mathrm{yr}$. During the longer cycle times, $M_{L}>6.0$ earthquakes occurred. With the exception of the 1963 sequence, seismicity migrated from north to south during the swarm sequence. If these patterns are repeated with regularity, then the next sequence may begin in the early 1990 's, since a $M_{L}>6.0$ earthquake has occurred during the present cycle.

It is difficult to study the interactions between the San Jacinto-Superstition Hills-Superstition Mountain system and the Imperial fault system with the available data set. The western edge of the Imperial Valley has been sparsely populated, and instrumental coverage has been poor, so that some $M_{L} \geqq 4.5$ events prior to 1940 may not have been detected. If the 1915 events occurred to the west of the Imperial fault, then there is a suggestion of a northwestward movement of $M_{L}>6.0$ events through time $(1915,1942$, and 1968) with a time interval of 25 to $30 \mathrm{yr}$ between events.

It is interesting to note that, as one moves away from the Imperial Valley in a northwest direction, the magnitudes of the $M_{L}>6.0$ earthquakes increase. This suggests heat flow may be controlling the extent of rupture during an earthquake, for the heat flow decreases as one moves away from the central Imperial Valley in this direction.

In the first half of this century, seismicity in the Mexico subregion gradually increased until two intensity VIII events occurred in 1927. The region was then quiescent until 1940 when maximum displacement along the Imperial fault occurred in this subregion and a number of immediate aftershocks also occurred here (Trifunac and Brune, 1970). A longer period of quiescence (18 yr) occurred before the 1979 event. Although the 1979 mainshock began in the Mexico subregion, surface faulting and most aftershocks occurred north of the border (Johnson and Hutton, 1982). These observations suggest that the 1940 earthquake relieved most of the strain accumulated in the region south of the border.

\section{CONCLUSIONS}

The improved locations and estimates of mislocation error provided by the relocation of earthquakes occurring from 1932 to 1973 reveal several interesting 
variations in spatial seismicity in the Imperial Valley. The increase in seismicity in regions northeast of the Imperial fault was seen only prior to the 1940 earthquake. Intensity reports for felt earthquakes before 1930 also suggest an increase in seismicity in regions surrounding the Imperial fault that may have begun as early as 1917. Although there is no strong evidence to show that the 1915 Imperial Valley earthquakes did not occur on the Imperial fault, the isoseismal patterns, description of the sequence, and seismicity patterns before and after the earthquakes may suggest locations off of the Imperial fault. In this case, seismicity between 1906 and 1940 would have formed a band that nearly encircled the Imperial fault north of $32^{\circ} 30^{\prime} \mathrm{N}$.

The relocations also support Johnson's (1979) observation that swarm sequences in the Imperial Valley tend to migrate from north to south. Swarm sequences appear to be cylical with periods of 6 to $12 \mathrm{yr}$. Five years prior to both the 1979 and 1940 mainshock, there were increases in swarm activity.

In both the 1940 and 1979 events, $M_{L} \geqq 4.5$ aftershocks only occurred for 2 months following the mainshock. These aftershock sequences were followed by periods of quiescence in the region within $30 \mathrm{~km}$ of the mainshock. Following the 1940 event, the quiescence lasted $10 \mathrm{yr}$. For the 1979 event, it still continues up to mid-1985. This is in contrast to earthquakes occurring near the edges of the Imperial Valley (1942 and 1968) that had aftershock sequences with $M_{L} \geqq 4.5$ events occurring within $30 \mathrm{~km}$ of the mainshock epicenter for up to $4 \mathrm{yr}$ after the mainshock.

If the 1915 event occurred west of the Imperial fault, then there has been a northwest progression of $M>6.0$ earthquakes from the central Imperial Valley to the end of the Coyote Creek fault from 1915 to 1968. The observed increase in event size with increasing distance from the central Imperial Valley is probably controlled by heat flow.

\section{ACKNOWLEDGMENTS}

This research benefited from discussions with $\mathrm{S}$. Wesnousky and M. Rymer. M. Baker reviewed an early draft of the manuscript. This research was supported by U.S. Geological Survey Contract 14-08$0001-21981$.

\section{REFERENCES}

Beal, C. H. (1915). The earthquake in the Imperial Valley, California, June 22, 1915, Bull. Seism. Soc. Am. 5, 130-149.

Brune, J. N. and C. R. Allen (1967). A low-stress-drop, low-magnitude earthquake with surface faulting: the Imperial, California, earthquake of March 4, 1966, Bull. Seism. Soc. Am. 57, 501-514.

Clark, M. M., K. K. Harms, J. J. Lienkaemper, D. S. Harwood, K. R. Lajoie, J. C. Matti, J. A. Perkins, M. J. Rymer, A. M. Sarna-Wojcicki, R. V. Sharp, J. D. Sims, J. C. Tinsley, III, and J. I. Ziony (1984). Preliminary slip-rate table and map of late-Quaternary faults of California, U.S. Geol. Surv., Open-File Rept. 84-106.

Coffman, J. L. and C. A. von Hake (1973). Earthquake History of the United States, U.S. Dept. of Commerce, National Oceanic and Atmospheric Administration, Environmental Data Service, $P u b$ lication 41-1, $208 \mathrm{pp}$.

Cory, H. T. (1913). Irrigation and river control in the Colorado River delta, Trans. Am. Soc. Civ. Engin. 76, 1204-1453.

Doser, D. I. and H. Kanamori (1986). Depth of seismicity in the Imperial Valley region (1977-1983) and its relationship to heatflow, crustal structure, and the October 15, 1979 earthquake, J. Geophys. Res. 91, 675-688.

Fuis, G. S., W. D. Mooney, J. H. Healy, G. A. McMechan, and W. J. Lutter (1982). Crustal structure of the Imperial Valley region in The Imperial Valley, California Earthquake of October 15, 1979, U.S. Geol. Surv. Profess. Paper 1254, 25-49.

Gutenberg, B. and C. F. Richter (1949). Seismicity of the Earth and Associated Phenomena, Princeton University Press, Princetõn, New York, 273 pp. 
Johnson, C. E. (1979). CEDAR-An approach to the computer automation of short-period local seismic networks; seismotectonics of the Imperial Valley of southern California, Ph.D. Thesis, California Institute of Technology, Pasadena, California, $343 \mathrm{pp}$.

Johnson, C. E. and D. P. Hill (1982). Seismicity of the Imperial Valley, in The Imperial Valley, California Earthquake of October 15, 1979, U.S. Geol. Surv. Profess. Paper 1254, 15-24.

Johnson C. E. and L. K. Hutton (1982). Aftershocks and preearthquake seismicity, in The Imperial Valley, California Earthquake of October 15, 1979, U.S. Geol. Surv. Profess. Paper 1254, 59-76.

Lee, W. H. K. and J. C. Lahr (1975). HYPO71 (revised): a computer program for determining hypocenter, magnitude, and first motion pattern of local earthquakes, U.S. Geol. Surv., Open-File Rept., 113 pp.

Louie, J. N., C. R. Allen, D. C. Johnson, P. C. Haase, and S. N. Cohn (1985). Fault slip in southern California, Bull Seism. Soc. Am. 75, 811-834.

Reagor, B. G., C. W. Stover, S. T. Algermissen, K. V. Steinbrugge, P. Hubiuk, M. G. Hopper, and L. M. Barnhard (1982). Preliminary evaluation of the distribution of seismic intensities, in The Imperial Valley, California Earthquake of October 15, 1979, U.S. Geol. Surv. Profess. Paper 1254, 251-258.

Richter, C. F. (1958). Elementary Seismology, W. H. Freeman and Co., San Francisco, California, 768 pp.

Sharp, R. V. (1982) Comparison of 1979 surface faulting with earlier displacements in The Imperial Valley, in the Imperial Valley, California, earthquake of October 15, 1979, U.S. Geol. Surv. Profess. Paper 1254, 213-221.

Thatcher, W. and T. C. Hanks (1973). Source parameters of southern California earthquakes, J. Geophys. Res. 78, 8547-8576.

Topozada, T. R. (1975). Earthquake magnitude as a function of intensity data in California and western Nevada, Bull. Seism. Soc. Am. 65, 1223-1238.

Topozada, T. R. and D. L. Parke (1982). Areas damaged by California earthquakes, California Division of Mines and Geology, Open File Rept. 82-17 SAC, 65 pp.

Topozada, T. R., D. L. Parke, and C. T. Higgins (1978). Seismicity of California, 1900-1931, California Division of Mines and Geology, Special Report 135, 39 pp.

Townley, S. D. and M. W. Allen (1939). Descriptive catalog of earthquakes of the Pacific coast of the United States 1769 to 1928, Bull. Seism. Soc. Am. 29, 1-298.

Trifunac, M. D. and J. N. Brune (1970). Complexity of energy release during the Imperial Valley, California, earthquake of 1940, Bull. Seism. Soc. Am. 60, 137-160.

Ulrich, F. P. (1941). The Imperial Valley earthquakes of 1940, Bull. Seism. Soc. Am. 31, 13-32.

Wood, H. O. (1941). Seismic activity in the Imperial Valley, California, Bull. Seism. Soc. Am. 31, 245254.

\author{
SEISMOLOGICAL LABORATORY \\ Division of Geological and Planetary Sciences \\ CALifornia Institute of TEChNOLOGY \\ Pasadena, California 91125 \\ CONTRIBUTION No. 4241
}

Manuscript received 5 July 1985 